\title{
Professional Competence of Future Engineers in the Process of Training of Computer Science Disciplines
}

\author{
Iryna Shumilova \\ the doctor of pedagogical sciences, \\ the assistant professor of the chair \\ of management and administration \\ Berdyansk State Pedagogical \\ University \\ Berdyansk, Ukraine \\ azkur-shif@ukr.net
}

\author{
Olena Ionova \\ the doctor of pedagogical sciences, \\ the professor of the chair of Natural \\ Sciences and Mathematics \\ Kharkov National Pedagogical \\ University named after \\ G.S.Skovoroda \\ Kharkov, Ukraine \\ ionova_54@mail.ru
}

\author{
Oksana Syvak \\ Department of Cultural Studies and \\ Information Activities \\ Mariupol State University \\ Mariupol, Ukraine \\ o.sivak@mdu.in.ua
}

\begin{abstract}
The theoretical principles of formation professional competences of future engineers are presented by means of informatics disciplines in this article. The issue of reforming of the higher system of education in Ukraine is considered by introducing a competent approach to the organization of the educational process. The role of teaching computer science disciplines is determined in the formation of professional competencies of future engineers, psychological and pedagogical background and methodical requirements as for the design of competence-oriented content of training of the informational disciplines of future engineers.
\end{abstract}

The article reveals the ways of practical implementation of the competence approach during the training of the computer science disciplines by future engineers and describes the developed model of formation of professional competencies of future engineers in the process of studying computer science disciplines. The peculiarities of forming professional competencies are determined during classroom sessions. The means of development of professional competencies and formation of research skills of future engineers are revealed by means of the using of competenceoriented tasks in students' independent work and methodical peculiarities of organization of educational computertechnology practice in the context of implementation of the competence approach. The experimental review of the effectiveness of the developed model is described as for the formation of professional competencies of future engineers in the process of training computer science disciplines.

Keywords-future engineers, competency, competence, professional competence, competence-oriented content of training, computer science disciplines.

\section{INTRODUCTION}

The main challenges that have to be taken into consideration when preparing modern engineers are the rapid development of science and technology, the need to implement strategy for sustainable development in all areas of human activity and a significant improvement in the practical training of engineers. The issue of the importance of competencies and their formation is one of the ways of studying the conditions of engineering education and it is necessary to create a set of competencies, that is associated with the effectiveness of teaching. The readiness of the university graduates to fulfill their professional duties at a high professional level is an indicator of their mobility in the present [6]. The modern practice of the educational system has its purpose as for strengthening the elements of competence that can include a set of main competences, skills, technologies that allow the university to provide students with educational services. Basic basis of engineering education should become not only academic disciplines, but also methods and forms of organization of educational activities [5].

In this article we consider of the concept of competence and identify the conditions of engineering education as the basis for the formation of a competency structure for effective teaching of computer science in achieving the methodological goals. As a result of the review of the literature, it is necessary to use different classifications of the set of competences that are determined for scientific and practical purposes as well as to determine their use and significance in connection with the concept of engineering education. In the conformity with the results of the study, the basic set which includes such elements as knowledge, skills and abilities, must also determine the readiness for the use of these elements that are interwoven with the concept of engineering education. The object of the research is the competence of the future engineer and its elements.

\section{MATERIALS AND METHODS}

The subject of the study is the interaction of elements of competence such as knowledge, skills and abilities. Methodology: review of literature, compilation and interpretation. The meanings and competency elements 
in various fields related to engineering, management, social sciences and human resources are considered when studying sources.

The American Council for Professional Development Engineers (ECPD) defines the term "engineering" as follows: "Creative application of scientific principles for the design or development of structures, machines, equipment, production processes or work on their use separately or in combination; designing or managing them with full knowledge of their design; predicting their behavior in certain operational decisions"[1]. Thus, people who are prepared for engineering activities must have the necessary knowledge, abilities, creative potential and professional skills [3].

Professional competence is a dynamic structure that is shown via the management of the individual and it is a person's ability to meet social needs, to solve successfully professional and problem tasks.

Among the elements of professional competence of future engineers are: scientific and technical (confirmed knowledge, skills and abilities, experience in the field of engineering, knowledge of engineering activities); information and communication technology (confirmed ability of the person to use computer technologies for guaranteed information and getting the information to meet their own individual needs and social requirements; energy management in engineering activities); information and management (confirmed ability to perform information management functions, organization and management of engineering activities). The pronounced substantive and specialized nature of these elements confirms that the main factor in ensuring the up-and-coming and future professional growth of future engineers is their training in computer science disciplines that determines their role as a source of systemic getting professional competences by students.

Getting an engineering education at least means to realize the purpose of various types of engineering activities in the relevant subject area, see the whole range of means of actions, to know how and be able to use the main ones, possess their basic technologies and understand what is at the entrance and what is desirably to get at the exit [4]. In order to form the professional competence of the future engineer it is necessary to design a competence-oriented content of training for the teacher of the university, which is understood with the problem of applied character, the means of solving are modern computer and communication technologies and the content of tasks corresponds to certain official duties.

The basic psychological and pedagogical conditions for designing the competence-oriented content of teaching of computer science disciplines is the construction of the process of teaching the informatics disciplines on the basis of system, complex, activity-oriented, personoriented, competence-oriented approaches; taking into consideration psychological and pedagogical peculiarities of the development of future engineers in the conditions of informational educational background providing with the content of training on the interest of future engineers in the profession; formation of knowledge as for the content of engineering activities and the skills to use the acquired knowledge to solve professional tasks; providing benefits to problem-based, research-based teaching methods.

The main methodological requirements for the organization of competence-oriented content of training of the computer disciplines of future engineers is aimed at: the formation of scientific and technical, information management, information and communication and technological competencies of all components of the educational process by establishing strong interdisciplinary links; training to transfer the acquired theoretical knowledge into the place of their direct use with maximum approaching to the real professionalengineering field and with the use of information and communication technologies; adherence to the principles of the development and use of competency-based tasks with the definition of their purpose and implementation in the educational process.

\section{RESULTS AND DISCUSSION}

In order to form the professional competencies of future engineers in the process of teaching computer science, we have developed a "Model for the formation of professional competencies of future engineers in the process of teaching computer science and its experimental verification" as an integral system of training.

The developed model contains three blocks: theoretical, operational-activity and criteria-estimating that in general covers all aspects of formation of professional competences of future engineers in the process of training of computer science disciplines.

Organizational-pedagogical conditions are direction of preparation of engineers for the complex formation of professional competencies; designing of competence-oriented content of computer science disciplines; step-by-step management of the process of formation of professional competencies; taking into consideration psychological and pedagogical and individual characteristics of students in the conditions of informational and educational environment.

The theoretical block of the model grounds the necessity of submission the training of the computer science disciplines to the formation of professional competencies of future engineers, training to transfer the acquired computer knowledge and skills into the field of their direct use that promote the competitiveness of the graduate-document scientist in the domestic and international labor markets.

In the theoretical block the following components are interwoven: preparation of specialists in engineers studies, formation of professional competencies of engineers in conformity with social order; the task: to master students with knowledge and skills in computer science disciplines; formation of skills in the use of information and communication technologies in solving competentoriented tasks; development of students' motivation 
for the active use of information and communication technologies in their professional activities; directing the student's personality to self-esteem, self-examination and professional self-improvement; psychological and pedagogical conditions, methodical requirements and principles: science approach, systemic, ensuring the developing nature of education, fundamentalism, variability and alternative, intersubject communications, educational interaction, consciousness and activity, professional orientation; approaches: systemic, complex, individual; components of professional competencies that need to be formed by students- engineers.

Operational-activity block of the model of formation of professional competences of future engineers in the process of training of the informational disciplines contains the stages of management in the process of formation of professional competencies (preparatory, basic, vocational); describes the classroom and extra-curricular learning resource, the content of training and methodical (technological) component (forms, methods and means of training that make students act, getting professional competencies in the process of teaching computer science disciplines). The educational content resource, criteria and indicators of the formation of professional competencies of future engineers are determined for each stage.

The main forms of organization of the educational process are lessons, independent educational and research work, practical training and control. We considered the type of interaction between the teacher and the student in determining the forms of students learning; the nature of the object and subject of study; the place and conditions of holding classes. Frontal, individual, group and individual-group forms of educational activity were allocated. Educational materials include printed educational materials (textbooks, manuals, methodical recommendations, charts), periodicals (newspapers, magazines, collections of scientific works), electronic educational materials (multimedia tutorials, presentations, disks), software, internet resources, multimedia projector, documents of various types, individual tasks, algorithmstips, tests. Not only lecture, explanation and annotation were selected among the methods of organization of students educational activities for the formation the system of knowledge, but also the search for information with the help of the Internet, the analysis of periodicals, the conclusion of glossaries, preparation of abstracts, etc.

For the development of analytical skills it is necessary to write essays using different forms of argumentation and reflexive assessment, articles review, critical review of the sources, informative and argumentative presentation. If we want to develop skills of solving professional problems, we have to think about the problem of definition, collection, analysis and interpretation of data, situation, justification of the algorithm of action, assessment of alternatives; for demonstration of professional information and communication actions thematic search, annotation, development of multimedia presentation support, database creation, site design, participation in the conference, thematic discussion and debate. If we develop skills of rational organization of educational activity, self-development, it is necessary to conduct diaries-organizers of time; create a personal bank of forms (technological cards), self-evaluation; mutual evaluation; mutual learning; group project.

The criteria-assessment block contains the following criteria: motivational-value that is based on the knowledge of the essence and structure of future professional activities and the possibilities of using computer science knowledge and skills, an interest and desire to execute competency-oriented tasks independently with the use of informational and communicational technologies; cognitive - the formation of a system of informative knowledge and skills in the performance of professional functions; activity - the ability to use information and communication technologies in their own professional activities; evaluative - the ability to evaluate their professional abilities, readiness for their development and indicators of the formation of professional competence of future engineers in the process of teaching computer science disciplines. The monitoring support for the implementation of the model of formation of professional competences of future engineers with the definition of the expected result, criteria of evaluation, diagnostic tools and types of control has been developed. An additional stage of adaptation in the primary position has been introduced.

The developed model of formation of professional competencies of future engineers in the process of teaching computer science offers a reorientation from the training of students of computer science disciplines to study the profession of engineer, theoretical knowledge is not formed verbally but through the active actions.

The model of the formation of professional competencies of future engineers in the process of teaching computer science disciplines according to the level of the system is the macro model, according to the level of formalization of information provision - the conceptual model, the place in the structure of scientific knowledge - epistemological, according to the orientation on the reproduction of certain aspects of the implementation of the competence approach - functional and structural with the way of communication between the presented data hierarchical network according to the purpose and tasks of the modeling - descriptive prognostic and with the time factor - dynamic.

In order to implement the developed model of the formation of professional competencies of students, engineers analyzed the educational standards and curricula from the specialty 121 "Software Engineering", the sequence of studying of computer science and professional disciplines was formed, the connection of the content of the professional skills of engineers and content modules of computer science disciplines was determined. A bank of competence-oriented tasks for all computer science disciplines was created. These tasks were divided into groups in conformity with the levels of complexity and duration of implementation for using in the classroom, independent study and research work of students, as well as during student computer and technology practice. 
Competent-oriented tasks during the computertechnological practice of students were formed in such a way that students had an opportunity to get acquainted with the document circulation of structural units, to form skills of using information and communication technologies in solving professional tasks, to create for themselves a database of forms (technological cards) for further professional activity. For example, the place of practice is the personnel management department. The content of the task is the development of an electronic form for employee registration, which allows to systematize information about the work experience, date of birth, information about the release of employees in the current year.

During the development and testing of the effectiveness of the model for the formation of professional competencies of future engineers with the help of computer science disciplines, a pedagogical experiment was held, consisting of three stages: summative, searching and formative assessment.

The test of the effectiveness of the developed model for the formation of professional competencies of future engineers in the study of the disciplines of the computer science cycle at the stage of the molding experiment was carried out according to the t-criteria of the Student. At the same time, all the samples were homogeneous and independent, and classes in the control and experimental groups of individual universities were held by the same teacher.

The only difference in learning in the experimental and control groups was the methodical system of teaching computer science disciplines. The experiment covered 13 experimental and 14 control groups of students. The total number of students who studied according to the experimental method was 343, and the control function of the experimental activity was carried out during the study of 351 students.

At the beginning of the experiment the hypotheses were put forward: zero $\mathrm{H}_{0}$ - the level of academic achievements in informatics in experimental groups of students is not higher than in control groups, alternative $\mathrm{H}_{1}$ - the level of educational achievements in computer science in experimental groups of students is higher than in control groups. By the t-criterion of the Investigator, the hypothesis $\mathrm{H}_{0}$ was adopted, that is the level of educational achievements in informatics in the groups was the same. After the experimental study the results of the state certification of the same students are analyzed according to the same criteria. Among the used tasks were professional exercises, the solution of which should identify the students' ability to use information and communication technologies. The hypothesis was adopted - the level of academic achievement among students in the experimental group is higher than that of the control group students. Figure 1 shows the results of learning the students at the beginning and at the end of the experiment, reflecting the results.

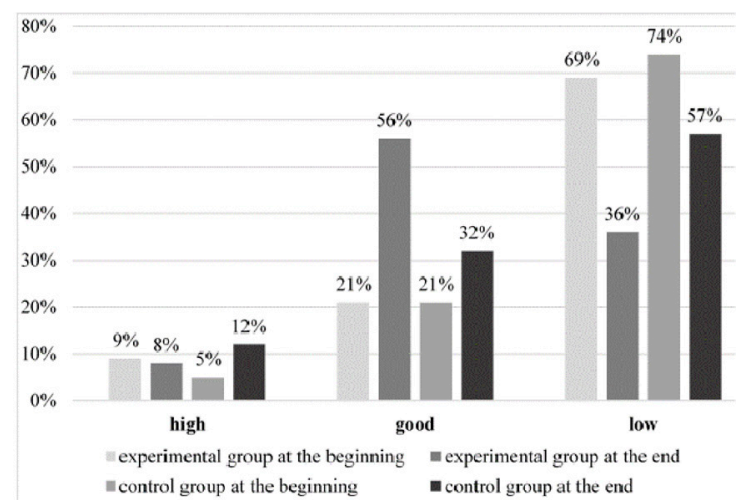

Fig.1 Diagram of student learning outcomes at the beginning and end of the experiment

In the process of forming an experiment, the criteria for the formation of professional competencies were also analyzed (Fig. 2).

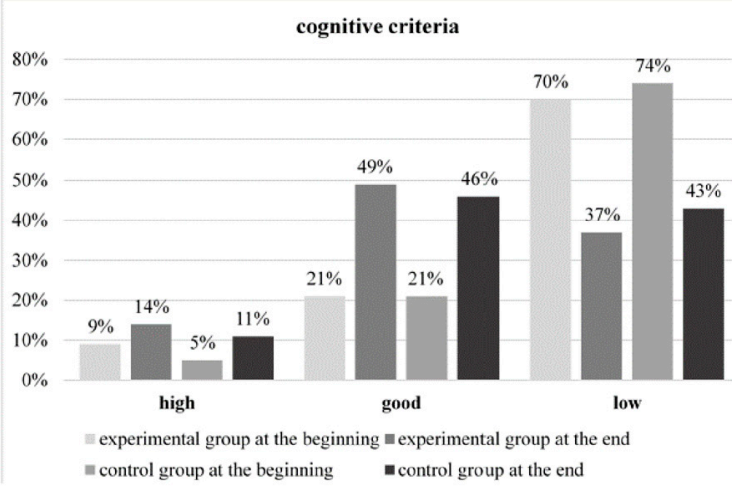

Fig.2 Diagrams of changes in the criteria for the formation of professional competencies (a)

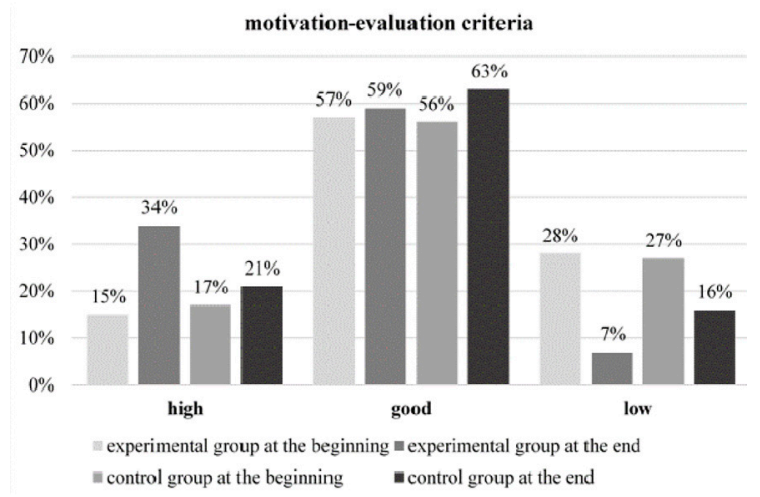

Fig.2 Diagrams of changes in the criteria for the formation of professional competencies (b)

Interviews made with university graduates who were working in their field found that those who studied in experimental groups adjusted more quickly to the workplace and some of the graduates held senior positions in one to two years.

\section{TESYINGAT THE UNIVERSITIES OF UKRAINE}

Implementation of the research results was carried out during the experimental work at the Mariupol State University and it has its special value.

The developed model of formation of professional competencies of future engineers in the process of teaching of computer science disciplines has been introduced into the practice of teaching in Donetsk National University, 
Mariupol State University, National University «Lviv Politechnik», Private Higher Educational University «European University», in Khmelnitsk institute of social researches [2].

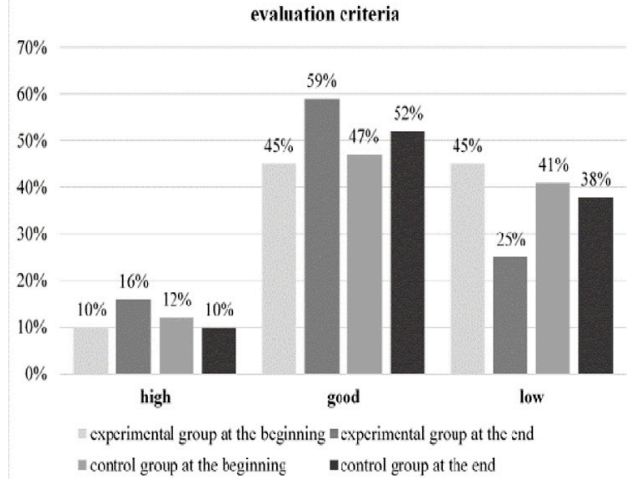

Fig.2 Diagrams of changes in the criteria for the formation of professional competencies $(\mathrm{c})$

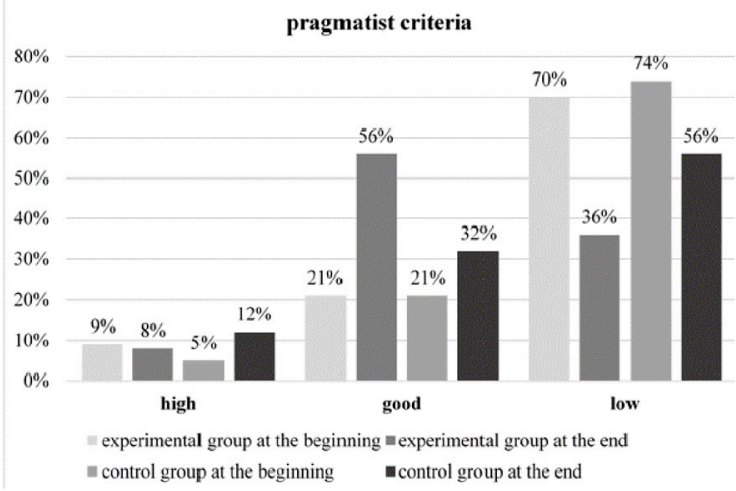

Fig.2 Diagrams of changes in the criteria for the formation of professional competencies (d)

\section{CONCLUSION}

The authors of the article conclude that the main dominant element of competence is the ability to act as well as knowledge and skills. The introduction of the model made it possible to determine the definite final results of the professional training of future engineers, positive changes in the quality of their preparation for work in the conditions of the information society, which is confirmed by the t-criteria of the Student.

\section{ACKNOWLEDGEMENTS}

According to the results of the experiment the effectiveness of the incorporating the integrity of the components of the model of professional competencies of future engineers during studying of educational subjects (theoretical, organizational-active and critical assessment block) that provide interaction of motivational, cognitive, active and evaluation criteria of forming professional competencies. This model presents the productivity, implementation of the competency approach not as discrete pedagogical phenomenon that changes certain aspects in the pedagogical process when studying computer science disciplines, but as a holistic system due to the transition of higher education to a new type of preparing specialists that contributes to lifelong learning.

\section{REFERENCES}

[1] Б. Бідій, “Інжинірингові послуги: нові можливості,” Налоговый кодекс, 2011. [Online serial]. Available: www.buhgalter.com.ua

[2] О.А. Сивак, Формування професійних компетентностей майбутніх документознавців у процесі навчання інформативних дисциплін. Бердянськ: автореферат, 2014.

[3] А.В. Журавський, А.Я. Яцейко, Н.Б. Дьяченко, Основи технічної творчості та наукових досліджень, Львів: Львівська політехніка, 2012.

[4] М. Карпаш, О. Карпаш, Є. Крижанівський, Вища інженерна освіта в умовах сталого розвитку суспільства, Вища освіта України, №2, с. 55-60, 2015.

[5] В.С. Харченко, Ред., Основы зеленой ИТ-инженерии. Моделирование облачных систем. Практикум. Министерство образования и науки Украины, Нац. аэрокосмический ун-т им. Н.Е. Жуковского “ХАИ”, 2016.

[6] І.Ф. Шумілова, Самоосвіта студентів 3 питань формування загальнокультурної компетентності, Наукові записки Бердянського державного педагогічного університету, Педагогічні науки, Вип. 1, с. 318-328, 2016. 